\title{
Thirty Years of Land-cover Change in Bolivia
}

\begin{abstract}
Land-cover change in eastern lowland Bolivia was documented using Landsat images from five epochs for all landscapes situated below the montane tree line at approximately $3000 \mathrm{~m}$, including humid forest, inundated forest, seasonally dry forest, and cloud forest, as well as scrublands and grasslands. Deforestation in eastern Bolivia in 2004 covered $45411 \mathrm{~km}^{2}$, representing $\sim 9 \%$ of the original forest cover, with an additional conversion of $9042 \mathrm{~km}^{2}$ of scrub and savanna habitats representing $17 \%$ of total historical land-cover change. Annual rates of land-cover change increased from $\sim 400 \mathrm{~km}^{2} \mathrm{y}^{-1}$ in the 1960 s to $\sim 2900 \mathrm{~km}^{2} \mathrm{y}^{-1}$ in the last epoch spanning 2001 to 2004. This study provides Bolivia with a spatially explicit information resource to monitor future land-cover change, a prerequisite for proposed mechanisms to compensate countries for reducing carbon emissions as a result of deforestation. A comparison of the most recent epoch with previous periods shows that policies enacted in the late 1990s to promote forest conservation had no observable impact on reducing deforestation and that deforestation actually increased in some protected areas. The rate of land-cover change continues to increase linearly nationwide, but is growing faster in the Santa Cruz department because of the expansion of mechanized agriculture and cattle farms.
\end{abstract}

\section{INTRODUCTION}

Land-cover change in tropical ecosystems is one of the most important ecological challenges facing modern society; potential global-scale impacts include catastrophic losses of biodiversity (1), increased global warming (2), and changes in weather patterns that could reduce agricultural production in the world's poorest countries (3). Despite numerous policy initiatives and multilateral assistance programs designed to decrease deforestation, countries in the developing world continue to experience high levels of deforestation because of economic and social phenomena that drive the expansion of the agricultural frontier (4-7). Proposals are now being advanced within the context of the United Nations Framework Convention on Climate Change (UNFCC) to compensate developing countries for conserving tropical forest; most proposals are based on lowering carbon emissions by reducing current deforestation rates (8). Whatever mechanism is eventually approved, parties to the agreement(s) will require baseline data on historical deforestation rates at the national level, whereas information at the subnational level will be a requisite for individual initiatives. Inevitably, countries will need to conduct a methodologically robust annual survey to document and certify any future reductions in the annual deforestation rate.

Currently, very few countries have access to reliable statistics on current and historical deforestation rates. Global deforestation is at near historical levels with an annual rate of $\sim 130000$ $\mathrm{km}^{2} \mathrm{y}^{-1}$; between $34000 \mathrm{~km}^{2} \mathrm{y}^{-1}$ and $44000 \mathrm{~km}^{2} \mathrm{y}^{-1}$ of this occurs in the Amazon (9). Brazil accounts for about $60 \%$ of Amazonian deforestation, with an annual rate of deforestation that has trended upward since monitoring began in 1988, with peaks in 1995 and 2004. The Brazilian rate has decreased the past two consecutive years, falling from a near high of 27429 $\mathrm{km}^{2} \mathrm{y}^{-1}$ in 2004 to $18793 \mathrm{~km}^{2} \mathrm{y}^{-1}$ in 2005 (10) and an unvalidated rate of only $13100 \mathrm{~km}^{2} \mathrm{y}^{-1}$ for 2006 (11). The Brazilian government contends that the recent reduction in deforestation is due to policy initiatives (12), but reduced demand for the commodities that drive deforestation may also be responsible. Similar data for the Andean Amazon is lacking because multitemporal measurements based on satellite imagery have not been systematically collected. This is the first published report in an effort to fill that information void.

Bolivia is situated on the southwestern edge of the Amazon Basin and has experienced large-scale deforestation during the past four decades (13-15). Deforestation in Bolivia is the result of a variety of economic and social forces that are representative of other parts of the developing world. The three major sources of deforestation are: i) immigration of peasants that practice subsistence agriculture; ii) mechanized agriculture for row crops; and iii) pasture establishment for livestock production (15). Like many developing countries, Bolivia has been the recipient of international assistance to promote the conservation of the country's biological resources. All of the Bolivian lowlands have been zoned for different types of land cover according to the principal of "best-use according to soil type;" an effort that has been financed by the World Bank and the Dutch government (16). Large tracts have been designated for forest management, and Bolivia recently announced that 2.2 million ha of humid tropical forest were "certified" as being sustainably managed according to international guidelines established by the Forest Stewardship Council (17). The country has also endeavored to create and manage numerous large protected areas, and approximately $17 \%$ of the lowlands are currently situated within a protected area (18). Simultaneously, the Bolivian state has initiated a process to review land titles, which incorporates mechanisms to guarantee the ancestral rights of native peoples (19). Rural lowland Bolivia is a culturally diverse region with social groups that range from indigenous peoples, traditional Hispanic residents, recent immigrant farmers, and industrial enterprises backed by foreign capital. Consequently, Bolivia can be viewed as a microcosm of social and economic phenomena characteristic of many parts of the developing world where different social groups compete for access to land and natural resources. Recent trends in landcover change in Bolivia provide a case study to evaluate the efficacy of policies to manage development and decrease deforestation.

We summarize how land-cover change has evolved in the past 30 years in lowland tropical Bolivia, an analysis that includes information from previous studies $(13,14)$, as well as new data covering the past 15 years. We document deforestation rates before and after the implementation of policies intended to reduce deforestation and protect biodiversity. In addition, we include data on the conversion of nonforest natural habitats that are necessary for a comprehensive assessment of biodiversity impacts. To our knowledge, this is the first comprehensive assessment of the loss of natural landcover types at the national level. More importantly, our study has created a spatially accurate database that provides a methodologically robust baseline for monitoring future landcover change. 


\section{MATERIALS AND METHODS}

The land-cover change analysis covers the period between 1975/ 76 and 2004/05; the first three epochs are adapted from a previous study (14), and the last two epochs are reported here. The fourth epoch compares 45 Landsat images obtained in 1991/92 (Landsat-5, Thematic Mapper) with images acquired in 2000/01 (Landsat-7, Enhanced Thematic Mapper). The fifth epoch is based on 18 satellite images (Landsat-5, Thematic Mapper) from areas that were the most dynamic in terms of land-cover change. Images before 2001 were acquired from the NASA Geocover project $(20,21)$. Later images were obtained from the Landsat-5 receiving station in Cuiabá, Mato Grosso, managed by the Brazilian Space Agency (INPE).

All images were coregistered to orthorectified images and the $1991 / 92$ to $2000 / 01$ epoch was classified by creating two-date, 12-band composite images that were subject to an unsupervised classification using the Isodata module of the Leica/Erdas software program. The classification procedure was conducted using 10 iterations and a threshold convergence of 0.95 to produce a thematic raster file with 125 spectral classes. The spectral classes were grouped into thematic classes based on spectral similarity and the functional type of land cover or landcover change. The $2000 / 01$ to $2004 / 05$ images were processed using the same Isodata module, but were not compiled into twodate composite images; instead the 2004/05 images were individually classified into land-cover classes, and the landcover change was derived by comparison with the previous epoch.

The classification procedure would sometimes provide insufficient discrimination within a thematic class and lead to an obvious mixing of distinct land-cover types with similar spectral signatures; in those cases, a second Isodata classification was conducted for that subpopulation of pixels. The final product was reviewed and edited and, if necessary, groups of pixels that were spectrally similar but functionally distinct were manually assigned to the appropriate land-cover class. The most common classification error was confusion among cover types with dense uniform canopies, particularly naturally regenerating native forest and anthropogenic secondary forest, as well as certain types of inundated forest and sunny montane slopes. Another common classification error was the confusion of natural grassland and scrub vegetation with cultivated pastures. The decision to assign a given spectral class or group of pixels to a natural or anthropogenic land-cover class was based on comparison to satellite images from the 1970s and 1980s. A detailed description of common classification errors and the editorial procedure has been described previously (22).

The completed images for the 1991/92 to 2000/01 epoch were compiled into a mosaic (termed NKM9101) that was compared with a previous multitemporal mosaic compiled by the University of Maryland (termed UMD7691) covering three temporal datasets: 1975/76, 1985/86, 1991/92 (14). The two mosaics differed in spatial resolution, geographic extent, and thematic stratification. The UMD7691 mosaic covered humid tropical forest above $20.5^{\circ} \mathrm{S}$ latitude, whereas the NKM9101 study included all land-cover types to the southern border ( $\sim 22^{\circ} \mathrm{S}$ latitude). The UMD7691 mosaic differed because of poor geometric registration of the older Landsat data, as well as from the differences in the classification of natural forest regeneration and anthropogenic secondary forest. Essentially the UMD7691 dataset was used to assign temporal epochs to anthropogenic land-cover types identified in the NKM9101 mosaic, which were then validated by comparison to Landsat imagery for the appropriate epoch between 1976 and 1992.

Land-cover change for the last temporal epoch $(2000 / 01$ to $2004 / 05$ ) was added to the composite mosaic to create a new multiepoch land cover and land-cover change map covering all of eastern Bolivia termed BOL7604 (Fig. 1). This dataset provides only partial coverage for the last temporal epoch, as it is based on 18 of a total 45 Landsat scenes that cover Bolivia; however, these 18 scenes incorporate $95 \%$ of the historical landcover change before 2001. At this point, the mosaic was filtered to eliminate small patches that tended to be classification errors, particularly those arising from the confusion between change that results from human land clearing and that which results from natural ecological processes. However, although the filtering procedure eliminates this kind of error it may introduce another type of error by eliminating small patch deforestation characteristic of peasant and indigenous agriculturalists, as well as the incipient phases of road building. The tradeoff in error was mitigated by using complimentary sets of polygons that stratified the study area into two separate areas: $i$ ) landscapes where landuse change was common and ii) landscapes where land-use change was uncommon. The filtering process was applied only to the first landscape category. Two separate filtering processes were used, both of which are modules of the Leica/Erdas software system: i) the nearest neighbor module converts minority pixels to majority classes using a cellular automata and ii) the clump and eliminate functions, which remove all patches smaller than a minimum criteria (2 ha). All three data sets (UMD7691, NKM9101, and BOL7604) are available on the Noel Kempff Mercado Museum web portal (23).

Mean annual rates of land cover change for the last two epochs were calculated using the two separate methods: i) a total value was calculated using as a denominator the weighted mean number of years per epoch, where the weight is based on the proportion of the total land-use change for individual scenes (9.84 for the 1992-2000 epoch and 3.71 for the 2001-2004 epoch) and ii) the sum of mean annual land-cover change calculated for individual Landsat scenes where the denominator is the specific time frame for that scene. The later metric is more accurate and was used for calculating national and departmental summary statistics; however, the first parameter was required for national-scale analyses such as land zoning categories and protected areas. We assume that all deforestation that occurred before the first image dataset (1956 to 1975) occurred in the approximately 20 years after the national government initiated a policy to promote the expansion of the agricultural frontier in the Bolivian lowlands; subsequent temporal epochs are also approximate periods that span from $1975 / 76$ to $1985 / 86$ (10 years) and to $1991 / 92$ (6 years).

The final mosaic (BOL7604) was validated by comparison to aerial videography acquired by over flights made between October and December 2004 (Fig. 1); flights were concentrated over dynamic landscapes that have experienced or are currently experiencing land cover change. Individual video frames were georeferenced using a geographic positioning system (GPS) linked to the video camera; the camera was programmed to capture only those video frames that coincided with a fresh GPS datum and the time of acquisition was recorded in the audio channel of the video camera. Land cover within video frames were classified for percent of land cover in three broad classes: i) forest; ii) all natural habitat, including forest, shrub, savanna, wetland, and water; and iii) anthropogenic cover, including second growth forest, pasture, crop land, bare soil, and urban area. The relative abundance of land cover was summarized for each video frame $(\sim 7-$ ha $)$, and this was compared to the relative land cover within a similar 7-ha rectangle around each GPS point from the land cover mosaic. The variance between the two information sources was calculated by comparing the relative area of each cover class (Fig. 2). No error analysis could be conducted for the previous 
Figure 1. Map of land-cover change (LCC) in eastern lowland Bolivia; the inset shows the approximate route of the validation over flights.

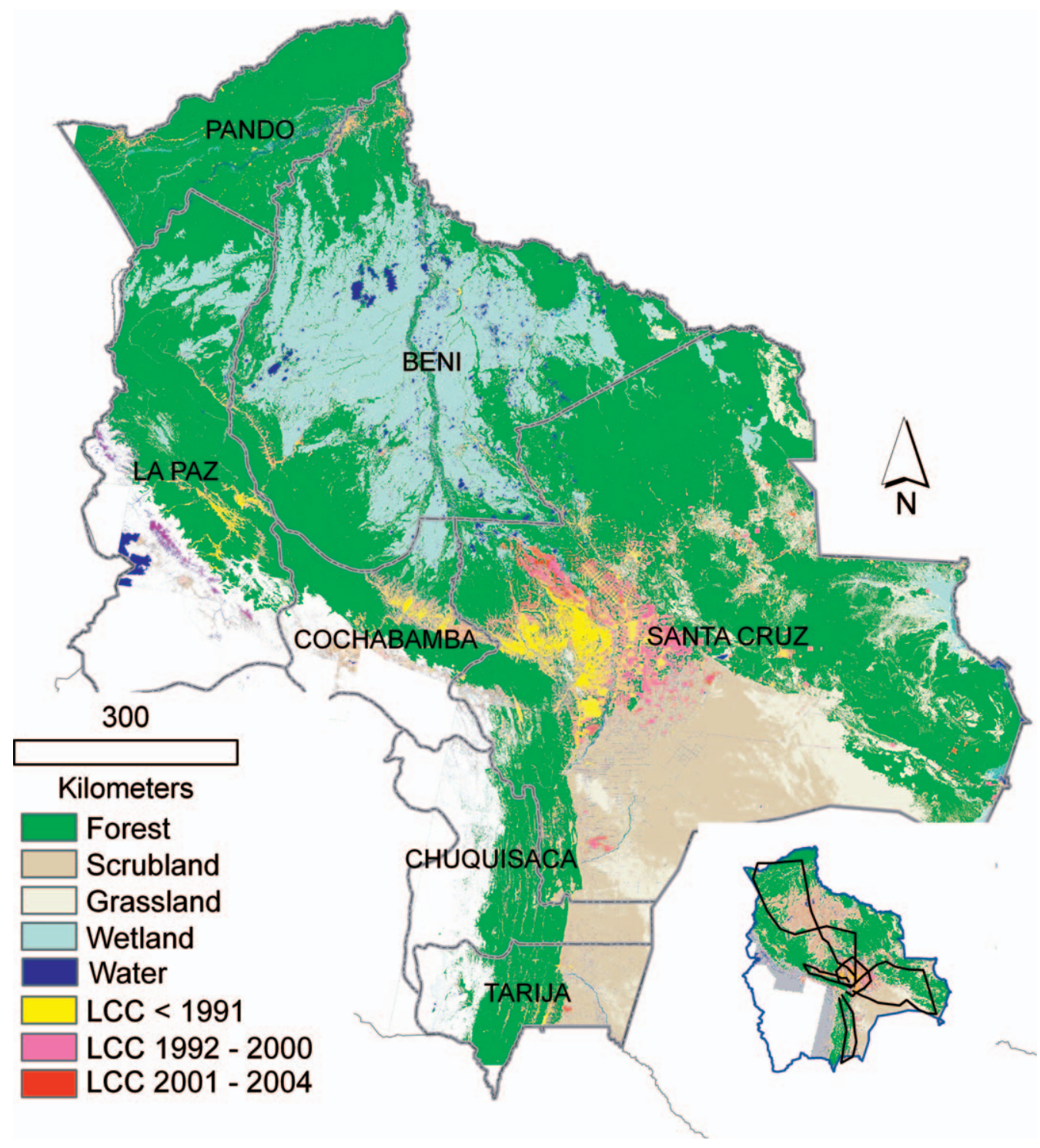

defines as forest and other wooded lands. Similarly, we provide data on land cover and land-cover change for all upland savanna formations including outliers of the Cerrado biogeographic region and the extensive inundated savannas of the Llanos de Moxos and Gran Pantanal regions of Bolivia (25). in Bolivia $(24,25)$ and the Forest Resource Assessment (FRA)
of the Food and Agricultural Organization (FAO), which defines forest as "land spanning more than 0.5 hectares with trees higher than 5 meters and a canopy cover of more than 10 percent, or trees able to reach these thresholds in situ" (9). The FRA definition also includes, in some instances, previously deforested land covered by secondary vegetation or forest plantations and even discounts clear cuts if the land is immediately replanted with trees. We have adopted a similar definition of forest, but exclude all secondary forest and tree plantations in the tabulation of our results to quantify the impact of land-cover change on natural habitats. Our use of the term forest refers to "natural" vegetation types such as rain forest, humid forest, semihumid forest, semideciduous forest, and deciduous forest $(24,25)$. We include humid and cloud forests on the eastern slope of the Andes Cordillera up to 3000 $\mathrm{m}$, but exclude montane dry forests from interior valleys because they are difficult to map using remote sensing technology (22). The Bolivian government, which provides summary data to the FRA, includes the Gran Chaco dry forest within its estimates of forest cover and forest cover change (26, 27); however, we treat the Gran Chaco vegetation type as a separate entity, as it is transitional between what the FRA

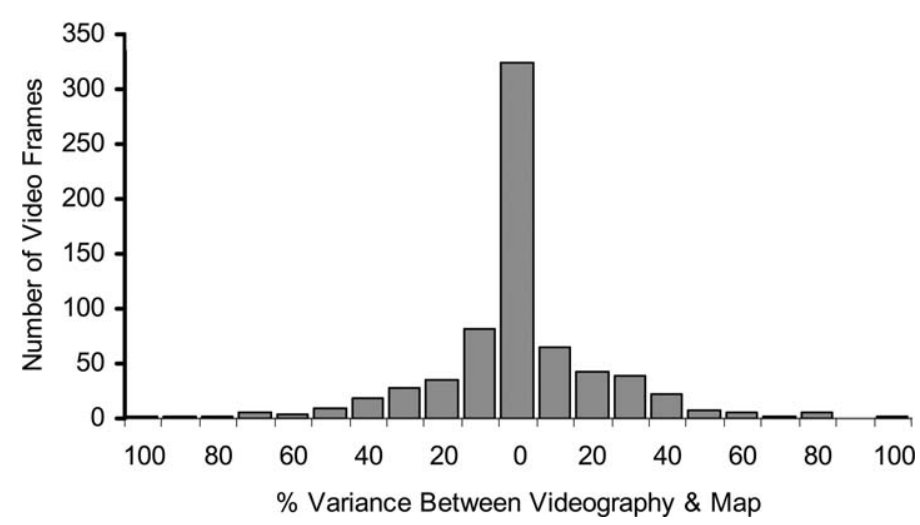

Figure 2. The variance for forest cover when comparing equivalent areas ( $\sim 7 \mathrm{ha})$ from the land-cover mosaic derived from classified Landsat images captured at the end of the last temporal epoch (2004-2005), with video frames captured on validation over flights made between October and December in 2005. 


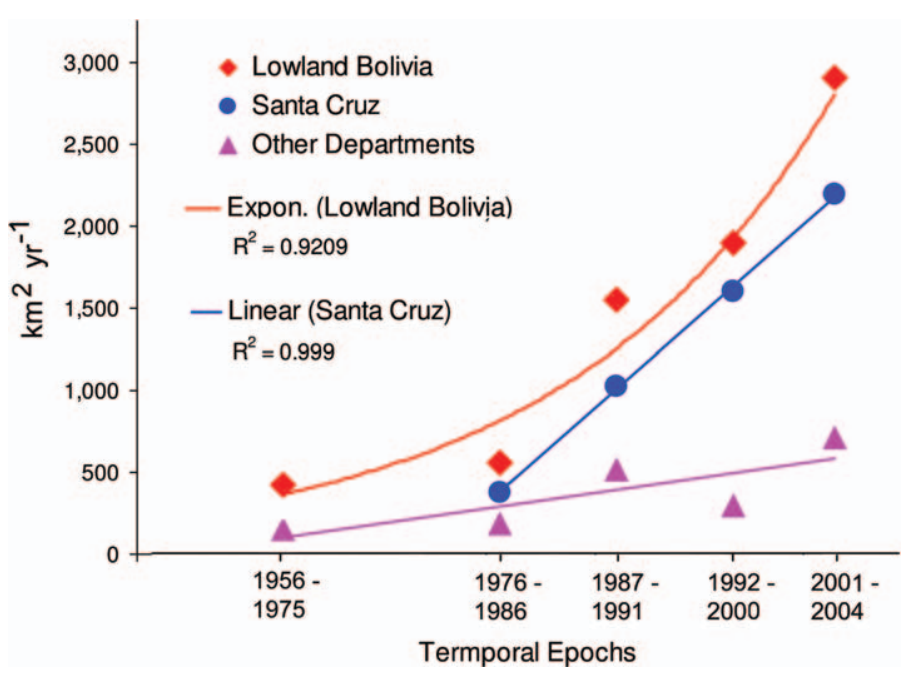

Figure 3. Rate of land-cover change in lowland Bolivia; other departments include the lowland regions of Cochabamba, La Paz, Beni, Pando, Chuquisaca and Tarija. The first epoch is based on a 20-year period starting in $\mathbf{1 9 5 6}$ at the start of modern settlement in lowland Bolivia.

\section{RESULTS}

Bolivia has experienced steadily increasing rates of land-cover change during the last three decades (Fig. 3). In earlier epochs the principal form of land-cover change was deforestation, because mechanized farmers, subsistence agriculturalists, and livestock producers all preferentially selected forest landscapes for conversion. However in the more recent epochs, other types of land cover change have become more prevalent, including $i$ ) conversion of savanna and scrub vegetation to cultivated pasture in the Gran Chaco and Cerrado biomes; ii) conversion of wetlands to mechanized farming by modification of natural drainage patterns; iii) the conversion of wetlands to paddy rice farming; and $i v$ ) the conversion of inundated wetlands to native pasture. Despite the increase of these other types of land-cover change, deforestation continues to represent $77 \%$ of the total (Table 1).

Seventy-five percent of all land-cover change has occurred in the Department of Santa Cruz, where the rate of change has increased dramatically in the last 20 years; if the first temporal epoch is taken into account, the rate of change is exponential (Fig. 3). The La Paz Department experienced relatively large rates of land-cover change in the 1960s when the humid valleys of the Yungas region were colonized by settlers from the Altiplano; however, the rate of change has declined both in real and relative terms since its peak in the 1970s. A similar pattern of migration and deforestation during the 1960s and 1970s occurred in the Chapare region of Cochabamba Department. However, the Chapare experienced a surge in deforestation in the period 1986-1991, followed by a sharp decline in the 1990s, then another increase in the most recent temporal epoch. In the other departments, there have been steady but smaller increments in land-cover change (Table 2).

The efficacy of land-use planning recommendations designed to foster appropriate land use and limit deforestation was evaluated by comparing rates of change in the most recent epoch after the implementation of the regulatory system in the late 1990s (Fig. 4a). The majority of land-cover change continues to occur in areas zoned for agricultural activity; however, deforestation tripled in areas that were zoned for forest management and doubled in areas zoned as "restricted use," which includes protected areas, as well as other landscapes that provide key ecosystem services such as steep slopes and river corridors. Land-cover change also increased on landscapes that were designated for extensive cattle ranching, a production system that has traditionally depended on native vegetation as grazing lands; unfortunately, landowners are now increasingly converting native savanna to cultivated pastures to improve productivity. In contrast, we show a decrease in land-cover change for the Gran Chaco region in the last epoch (Table 1), due largely to a reduction in the conversion of these landscapes to the cultivation of row crops because of recurrent drought.

Protected areas have been successful in conserving large areas of intact natural ecosystems (28). Our results reaffirm the generally positive trend for the 1990s when the rate of deforestation decreased in almost all protected areas. However, our results show a reversal of that trend in the most recent epoch (Fig. 4b). Three protected area complexes, Amboró, Carrasco, and Isiboró-Securé, have suffered historically high levels of land-cover change, and all three show increased deforestation rates in the last temporal epoch after showing declines during the 1990s (Table 3). The Amboró protected area has been subdivided into units with differing degrees of protection; areas zoned as "national park" have relatively low rates of land-cover change, whereas the multiple use area has higher rates of land-cover change. Most protected areas are in relatively remote areas and experience relatively low annual rates of land-cover change. The protected areas that experienced the largest total deforestation and the largest increase in deforestation in the most recent epoch were those situated adjacent to peasant colonization zones where the cultivation of illicit crops is widespread.

The validation analysis demonstrated that the land-cover mosaic is an accurate map of land cover for lowland Bolivia. The variation between the map and the video frames overestimates the real error rate because over flights were concentrated along major highways and agricultural regions, whereas almost $75 \%$ of lowland Bolivia is covered by expanses of unbroken forest or savanna where the difference between the two information sources approaches zero. However, the validation analysis over dynamic anthropogenic landscapes showed considerable variation between the videography and the

Table 1. Land-cover change (LCC) and LCC rates for different land cover types.

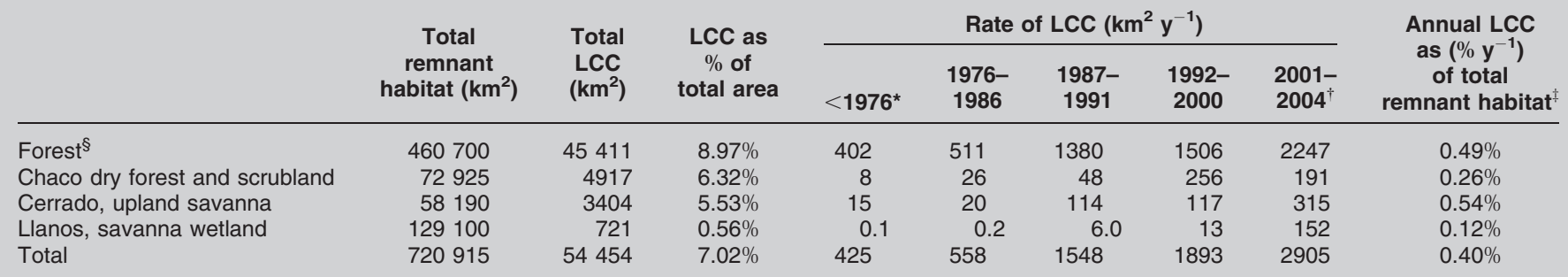

*This statistic is based on a 20 -year period starting in 1956. "The data for the last epoch is based on 18 Landsat scenes with historically high levels of land-cover change representing more than $95 \%$ of land-cover change in previous epochs. ${ }^{\ddagger}$ Annual LCC rate is based on the rate of change measured in the last epoch and the existing total remnant habitat that was documented at the end of that epoch. Includes rain forest, cloud forest, humid forest, semi-humid forest, semi-deciduous forest, and deciduous forest in lowland Bolivia. 
Table 2. Land cover and land-cover change (LCC) in the lowland sectors of the seven Bolivian Departments included in the study: (A) total natural habitat and (B) natural forest habitat.

\begin{tabular}{|c|c|c|c|c|c|c|c|}
\hline \multirow[b]{2}{*}{ A } & \multirow{2}{*}{$\begin{array}{c}\text { Total } \\
\text { remnant } \\
\text { habitat }\left(\mathbf{k m}^{2}\right)\end{array}$} & \multicolumn{5}{|c|}{ Rate of LCC $\left(\mathrm{km}^{2} \mathrm{y}^{-1}\right)$} & \multirow{2}{*}{$\begin{array}{c}\text { Annual LCC } \\
\text { as }\left(\% y^{-1}\right) \\
\text { of total } \\
\text { remnant habitat }\end{array}$} \\
\hline & & $<1976^{\star}$ & $1976-1986$ & $1987-1991$ & $1992-2000$ & $2001-2004^{\dagger}$ & \\
\hline Beni & 201384 & 15 & 25 & 138 & 85 & 227 & $0.11 \%$ \\
\hline Chuquisaca & 21882 & 0 & 0 & 1 & 13 & 16 & $0.07 \%$ \\
\hline Cochabamba & 24176 & 37 & 50 & 218 & 101 & 240 & $0.99 \%$ \\
\hline La Paz & 73322 & 67 & 67 & 40 & 51 & 44 & $0.06 \%$ \\
\hline Pando & 58770 & 7 & 12 & 97 & 30 & 90 & $0.15 \%$ \\
\hline Santa Cruz & 316070 & 270 & 375 & 1028 & 1598 & 2192 & $0.69 \%$ \\
\hline Tarjia & 25311 & 28 & 28 & 27 & 15 & 95 & $0.38 \%$ \\
\hline \multirow[t]{2}{*}{ Total } & 720915 & 425 & 558 & 1548 & 1893 & 2905 & $0.40 \%$ \\
\hline & Total & \multicolumn{5}{|c|}{ Rate of deforestation $\left(\mathrm{km}^{2} \mathrm{y}^{-1}\right)$} & \multirow{2}{*}{$\begin{array}{c}\text { Annual } \\
\text { deforestation } \\
\text { as }\left(\% y^{-1}\right) \\
\text { of total } \\
\text { remnant forest }\end{array}$} \\
\hline B & forest $^{\S}\left(\mathbf{k m}^{2}\right)$ & $<1976^{\star}$ & 1976-1986 & $1987-1991$ & $1992-2000$ & $2001-2004^{\dagger}$ & \\
\hline Beni & 98028 & 15 & 25 & 134 & 80 & 208 & $0.21 \%$ \\
\hline Chuquisaca & 15161 & 0 & 0 & 0 & 9 & 4 & $0.03 \%$ \\
\hline Cochabamba & 20745 & 37 & 50 & 218 & 101 & 238 & $1.15 \%$ \\
\hline La Paz & 62258 & 67 & 67 & 38 & 51 & 41 & $0.07 \%$ \\
\hline Pando & 58213 & 7 & 12 & 96 & 30 & 88 & $0.15 \%$ \\
\hline Santa Cruz & 192612 & 249 & 329 & 870 & 1229 & 1608 & $0.84 \%$ \\
\hline Tarjia & 13683 & 27 & 28 & 23 & 7 & 59 & $0.43 \%$ \\
\hline Total & 460700 & 402 & 495 & 1380 & 1506 & 2247 & $0.49 \%$ \\
\hline
\end{tabular}

land cover mosaic (Fig. 2). The source of this variation is in part due to misclassification errors derived of the Landsat images, particularly the confusion of second-growth forest with degraded remnant forest patches. However, much of the variance came from the videography; airplane roll, periodic changes in elevation, and GPS error caused the reference video frame to capture slightly different polygons than corresponding polygons extracted from the land cover map.

\section{DISCUSSION}

Land-cover change in Bolivia is subject to temporal and spatial variation that is the result of international markets and domestic social forces. Demand for sugar and cotton drove deforestation in Santa Cruz in the 1970s during an era of subsidized credit, whereas the recent exponential growth in the rate of deforestation has coincided with policies that favor the private sector, strategic investments in infrastructure, and favorable market conditions for soy $(6,15)$. In contrast, deforestation in the Chapare region of Cochabamba during the 1980s has been attributed to tolerance of coca cultivation that coincided with the collapse of the international mineral prices and the immigration of thousands of ex-miners (29). The Bolivian authorities in coordination with international agencies mounted an aggressive program to eradicate coca in the 1990s, which coincided with a dramatic decrease in the deforestation rate; recent political events have led to a renewed increase in coca cultivation (30) and deforestation (Table 2).

Our results demonstrate the need for a broader perspective of land-cover change. Public debate has focused on tropical deforestation with less attention paid to habitat conversion of dry forests, scrubland, and grassland ecosystems. Most of the savanna and scrubland habitats of eastern Bolivia are part of the Cerrado and Gran Chaco bioeographic regions, which are under severe pressure in neighboring countries $(31,32)$. Wetland conversion is one of the most controversial forms of land-cover change in temperate countries but is seldom mentioned in forums in tropical regions (33). Our study shows that wetland

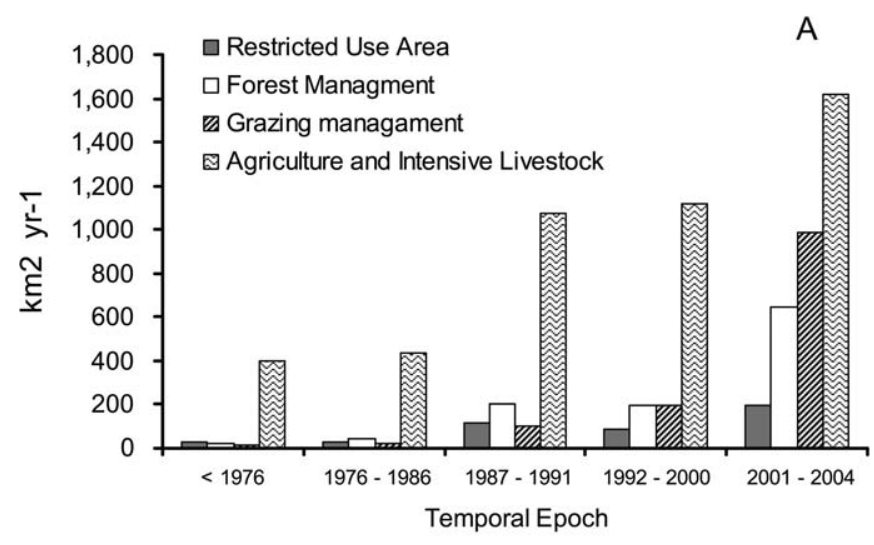

B

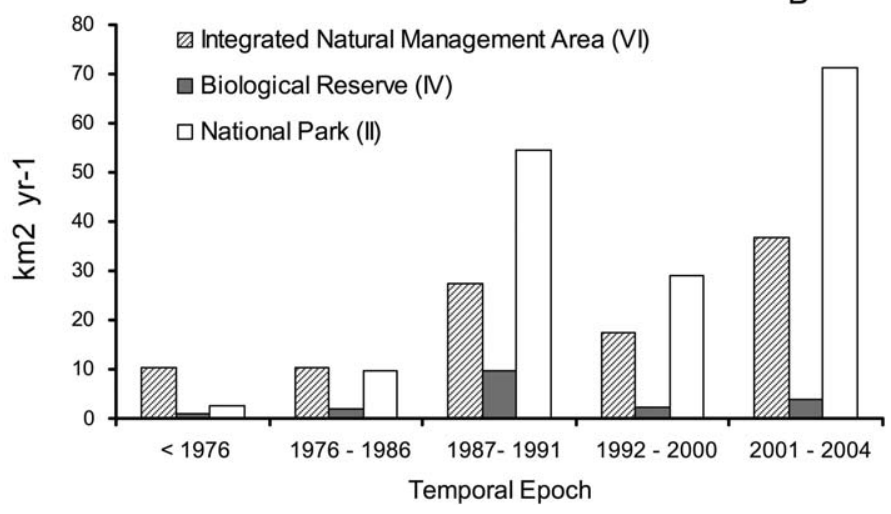

Figure 4. (A) Rate of land-cover change for four categories of landuse zoning recognized by the Bolivian government. (B) Rate of landcover change in three categories of the Bolivian system of national protected areas. (IUCN Categories in parenthesis); both graphics cover all of lowland Bolivia. Note: The term restricted use is not equivalent to protected area and includes other landscapes where agriculture is deemed inappropriate. 
Table 3. Land-cover change (LCC) and LCC rates for the three most threatened areas of the Bolivian Protected Areas Network.

\begin{tabular}{|c|c|c|c|c|c|c|c|c|c|}
\hline & \multirow[b]{2}{*}{$\begin{array}{c}\text { Total } \\
\text { remnant } \\
\text { habitat }\left(\mathbf{k m}^{2}\right)\end{array}$} & \multirow[b]{2}{*}{$\begin{array}{c}\text { Total } \\
\operatorname{LCC}\left(\mathbf{k m}^{2}\right)\end{array}$} & \multirow[b]{2}{*}{$\begin{array}{c}\text { LCC as } \\
\% \text { of } \\
\text { total area }\end{array}$} & \multicolumn{5}{|c|}{ Rate of LCC $\left(\mathrm{km}^{2} \mathrm{y}^{-1}\right)$} & \multirow{2}{*}{$\begin{array}{c}\text { Annual } \\
\text { rate of LCC } \\
\text { as }\left(\% y^{-1}\right) \text { of } \\
\text { total remnan } \\
\text { habitat }^{\ddagger}\end{array}$} \\
\hline & & & & $<1976^{\star}$ & $\begin{array}{c}1976- \\
1986\end{array}$ & $\begin{array}{c}1987- \\
1991\end{array}$ & $\begin{array}{c}1992- \\
2000\end{array}$ & $\begin{array}{l}2001- \\
200^{\dagger}\end{array}$ & \\
\hline $\begin{array}{l}\text { Isiboro Securé National Park \& } \\
\text { Indigenous Area }\end{array}$ & 11819 & 406 & $3.3 \%$ & 0.1 & 3.8 & 28.4 & 9.0 & 33.1 & $0.28 \%$ \\
\hline Carrasco National Park & 5472 & 493 & $8 \%$ & 1.7 & 2.0 & 22.9 & 18.1 & 35.3 & $0.64 \%$ \\
\hline $\begin{array}{l}\text { Amboró Integrated Natural } \\
\text { Management Area }\end{array}$ & 1078 & 445 & $29 \%$ & 7.1 & 7.6 & 17.7 & 8.9 & 14.3 & $1.33 \%$ \\
\hline Amboró National Park & 4338 & 24 & $0.6 \%$ & 0.1 & 0.5 & 1.4 & 0.5 & 1.8 & $0.04 \%$ \\
\hline 20 Other Protected Areas ${ }^{\star \star}$ & 127355 & 497 & $0.4 \%$ & 4.1 & 9.0 & 19.9 & 12.1 & 32.4 & $0.03 \%$ \\
\hline Total & 150061 & 1865 & $1.2 \%$ & 13.0 & 22.9 & 90.2 & 48.7 & 116.9 & $0.08 \%$ \\
\hline
\end{tabular}

conversion is becoming increasingly important in Bolivia and is probably also occurring in other tropical countries.

Tropical deforestation is a major source of carbon emissions, contributing an estimated $25 \%$ of global greenhouse gases (34). Current rules of the Clean Development Mechanism (CDM) limit natural resource-based carbon offsets to reforestation or a-forestation projects; landscapes eligible for CDM projects under the current rules must have been deforested before the Kyoto Protocol in 1991. However, half of the total area deforested in lowland Bolivia $\left(\sim 22400 \mathrm{~km}^{2} \mathrm{y}^{-1}\right)$ has been deforested since 1991 and current annual deforestation rates represent $10 \%$ of the area eligible for CDM projects, a rate that has been growing rapidly for three decades (Fig. 2). No CDM reforestation projects have been approved in Bolivia, and those in the planning stage represent only a miniscule portion of the total eligible area $(<0.01 \%)$. The Bolivian case demonstrates the ineffectiveness of the current rules for reducing carbon emissions from tropical countries.

Recent proposals call for the UNFCCC to create a mechanism that certifies deforestation avoidance to reduce carbon emissions and provide tropical countries with an economic incentive to conserve forest ecosystems (8). All of these proposals will require a baseline deforestation rate as a reference point for certifying future reductions. Our results demonstrate that this baseline can vary enormously depending upon the time period chosen, while the social feasibility and economic value of future reductions will vary greatly depending on the base-line. If the period 1976-1990 was used as the baseline, Bolivia would have to reduce its current rate of deforestation by more than $50 \%$ to be eligible for compensation, whereas the economic value of an offset would vary by almost $50 \%$ depending on whether the epoch 1990-2000 or 2001-2004 was used as the baseline.

Deforestation avoidance programs will be accompanied by specific policies that regulate, subsidize, or tax certain kinds of land use; consequently, governmental authorities will require frequent updated land-cover change studies to implement those policies and certify compliance (12). Accuracy and precision will be important attributes as land-cover change studies migrate from the sphere of research into mechanisms that monitor enforcement of land-use regulations. Our results confirm that Landsat classifications are robust at large scales; our study is both unbiased and accurate because overestimates canceled out underestimates of deforestation. However, the lack of precision over dynamic anthropogenic landscapes (Fig. 2) shows that caution is necessary when using land-cover classifications derived from Landsat-type images at local scales.

Bolivia has been the recipient of numerous initiatives designed to manage the environmental and social impacts of development. Many of these policies continue to be recommended throughout the Amazon, particularly as part of sustainable development plans that accompany infrastructure projects (35). Some of these policies may be incorporated into deforestation avoidance projects under the aegis of a modified UNFCCC or as part of similar voluntary programs. Our results show that these policy initiatives have had only a limited success in Bolivia (Fig. 3), largely because regulatory mechanisms lack economic incentives. Consequently, deforestation is not slowing but increasing at consistently greater rates of change. Development throughout the Amazon will continue to expand because of a regional consensus to physically integrate the national economies of the continent (36). Unless innovative measures with concrete economic incentives are implemented, the growth in carbon emissions from deforestation will dramatically increase in the short term with local, regional, and global consequences.

\section{References and Notes}

1. Myers, N., Mittermeier, R.A., Mittermeier, C.G., Fonseca, G.A.B. and Kent, J. 2000 Biodiversity hotspots for conservation priorities. Nature 403, 853-858

Houghton, R.A. 2003. Revised estimates of the annual net flux of carbon to the atmosphere from changes in land use and land management. Tellus 55, 378-390.

Avissar, R. and Werth, D. 2005. Global hydroclimatological teleconnections resulting from tropical deforestation. J. Hydromet. 6, 134-145.

4. Foley, J., DeFries, R., Asner, G.P., Barford, C.G., Bonan, G.B., Carpenter, S.R. Chapin, F.S.I., Coe, M.T., et al. 2005. Global consequences of land use. Science 309 , $570-574$

. Angelsen, A. and Kaimowitz, D. 1999. Rethinking the causes of deforestation: lessons from economic models. World Bank Research Observer 14, 73-98

Hecht, S.B. 2005. Soybeans, development and conservation on the Amazon frontie Development and Change 36, 375-404.

Margullis, S. 2003. Causas do Desmatamento da Amazonia Brasileira. World Bank, Washington, DC, $77 \mathrm{pp}$.

8. UNFCCC 2006. Background paper for the workshop on reducing emissions from deforestation in developing countries, 30 August-1 September 2006, Rome, Italy. (http://unfecc.int/methods_and_science/lulucf/items/3757.php)

FAO 2005. Global Forest Resource Assessment 2005. (http://www fao.org/forestry)

10. PRODES 2006. Projeto prodes, monitoramento da floresta amazônica brasileira por PRODES 2006. Projeto prodes, monitoramento da floresta amazonica brasileira por
satelite, Instituto Nacional de Pesquizas Espasciais (INPE). (http://www.obt.inpe.br/ prodes/) (In Portuguese)

11. Agência Brasil 26 October 2006. Desmatamento na Amazônia entre 2005 e 2006 deve ter nova redução de 30\%. (http://www.agenciabrasil.gov.br/noticias/2006/10/26/materia. 2006-10-26.2984420233/view) (In Portuguese).

12. The Brazilian state has several initiatives to monitor and control deforestation, including the SLAPR program to regulate land-clearing in the Brazilian State of Mato Gosso (http:/Www socioambientalorg/e/nsa/detalheid=2052) and the real-time deforestation (htp:// in .socioambient. monito $\operatorname{deter}$.

13. Steininger, M.K., Tucker, C.J., Ersts, P., Killeen, T.J., Villegas, Z. and Hecht, S.B. 2001 Clearance and fragmentation of tropical deciduous forest in the Tierras Bajas, Sant Cruz, Bolivia. Cons. Biol. 15, 865-866.

14. Steininger, M.K., Tucker, C.J., Townshend, J.R.G., Killeen, T.J., Desch, A., Bell, V and Ersts, P. 2001. Tropical deforestation in the Bolivian Amazon. Envir. Conserv. 28 127-234.

15. Pacheco, P. 2006. Agricultural expansion and deforestation in the lowlands bolivia: the import substitution versus the structural adjustment model. Land Use Policy 23, 205-225.

6. Anonymous. 2003 Ordenamiento Territorial en Bolivia, Ministerio de Desarrollo Sostenible y Planificacion,

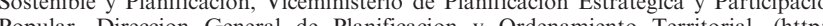
Popular, Direccion Gene Vice

17. Consejo Boliviano de Certificación Forestal Voluntario. 2006. Operaciones certificadas en Bolivia por buen manejo forestal y cadena de custodia. (http://www.consejoforestal. org.bo) (In Spanish). 
18. Olivieri, S., Waller, R. and Borja, C. 2005. World Database of Protected Areas. Center for Applied Biodiversity Science, Conservation International and the United Nations Environment Program, World Conservation Monitoring Centre. CD-ROM.

19. Martinez, J.A. (ed). 2000. Atlas Territorios Indígenas en Bolivia. Centro de Planificación Territorial Indígena de la Confederación de Pueblos Indígenas de Bolivia (CPTICIDOP), Santa Cruz, Bolivia, 259 pp. (In Spanish).

20. Global Land Cover Facility, Department of Geography, University of Maryland. 2007. (http://www.glcf.umd.edu)

21. Tucker, C.J., Grant, D.M and Dykstra, J.D 2004 NASA's Global Orthorectified Landsat Data Set. Photogrammetric Engineering \& Remote Sensing 70, 313-322.

22. Killeen, T.J., Siles, T.M., Soria, L., Correa, L. and Oyola, N. 2005. La Estratificación de vegetación y el cambio de uso de suelo en Las Yungas y El Alto Beni de La Paz. Ecologia en Bolivia 40, 32 69. (In Spanish).

23. Noel Kempff Mercado GIS Lab. 2007. (http://www.museonoelkempff/org)

24. Killeen, T.J., Beck, S.G. and Garcia E, E. 1993. Guía de Arboles de Bolivia, Herbario Nacional de Bolivia and Missouri Botanical Garden, La Paz, Bolivia, 958 pp.

25. Navarro, G.G. and Maldonado, M. 2002. Geografína Ecológica de Bolivia, Vegetación y Amabientes Acuáticos. Editorial: Centro de Ecología Simón Patiño-Departamento de Difusión, Cochabamba, Bolivia. 719 pages

26. MDSMA 1994. Mapa forestal de Bolivia. Memoria explicativa. Secretaría Nacional de Recursos Naturales. Ministerio de Desarrollo Sostenible y Medio Ambiente. La Paz. (In Spanish).

27. Bruner, A.G., Gullison, R.E., Rice, R. E. and Fonseca, G.A.B. 2000. Effectiveness of parks in protecting tropical biodiversity. Science 291, 125-128.

28. Klein, H. 2003. A Concise History of Bolivia. Cambridge University Press, Cambridge, $336 \mathrm{pp}$.
29. UNODC 2006. Bolivia, Coca cultivation survey. United Nations Office of Drugs and Crime and Vice-Ministry for Alternative Development. (http://www.unodc.org/unode/ en/crop_monitoring.html)

30. Klink, C. and Machado, R.B. 2005. Conservation of the Brazilian Cerrado, Conservation Biology 19, 707-713.

31. Zak, M.R., Cabido, M. and Hodgson, J.G. 2004. Do subtropical seasonal forests in the Gran Chaco, Argentina, have a future? Biological Conservation 120, 589-598.

32. Frazier, S. 1999. Ramsar Sites Overview. Wetlands International, Gland, Switzerland, 42 pp.

33. IPCC 2007. Special Report on Emissions Scenarios. Intergovernmental Panel on Climate Change. (http://www.grida.no/climate/ipcc/emission/076.htm)

34. Examples include the Environmental Action Plan for the Corridor Puerto Suarez-Santa Cruz (Bolivia) and The Sustainable Development Plan for BR163(Pará, Brazil).

35. IADB 2006. Building a New Continent, a Regional Approach to Strengthening South Amarica Infrastructiure, Initiative For the Integration of the Regional Infrastructure of South America, InterAmerican Development Bank, Washington, DC and other full list of priority projects.

36. Financial support for this study was provided to the Friends of the Noel Kempff Mercado Museum Foundation by the Critical Ecosystem Protection Fund (CEPF), The Nature Conservancy, World Wildlife Fund, and the Vice Ministry for the Environment of the Bolivian government, as well as by the Gordon and Betty Moore Foundation via its commitment to Conservation International.

37. First submitted 6 March 2006. Accepted for publication 31 May 2007.
Timothy J. Killeen is a Senior Research Scientist at the Center for Applied Biodiversity Science (CABS) and Scientific Advisor at the Museo Noel Kempff Mercado. His address: Center for Applied Biodiversity Science at Conservation International, 1919 M Street NW, Washington DC 20036, USA.

E-mail: t.killeen@conservation.org

Veronica Calderon is a spatial analyst. Her address: Departmento de Geografía, Museo de Historia Natural Noel Kempff Mercado, Universidad Autónoma Gabriel René Moreno, Avenida Irala 565, Santa Cruz, Bolivia.

E-mail: vcalderon@museonoelkempff.org

Liliana Soria is a spatial analyst. Her address: Departmento de Geografía, Museo de Historia Natural Noel Kempff Mercado, Universidad Autónoma Gabriel René Moreno, Avenida Irala 565, Santa Cruz, Bolivia.

E-mail: Isoria@museonoelkempff.org

Belem Quezada is a spatial analyst. His address: Departmento de Geografía, Museo de Historia Natural Noel Kempff Mercado,
Universidad Autónoma Gabriel René Moreno, Avenida Irala 565, Santa Cruz, Bolivia.

E-mail: bquezada@museonoelkempff.org

Marc K. Steininger is a Scientific Director at the Regional Analysis Program in CABS. His address: Center for Applied Biodiversity Science (CABS) at Conservation International, 1919 M Street NW, Washington DC 20036, USA.

E-mail: m.steininger@conservation.org

Grady Harper is a remote sensing specialist in CABS. His address: Center for Applied Biodiversity Science (CABS) at Conservation International, 1919 M Street NW, Washington DC 20036, USA.

E-mail: g.harper@conservation.org

Luis A. Solórzano is Senior Science Program Officer at the Gordon and Betty Moore Foundation. His address: Gordon and Betty Moore Foundation, The Presidio of San Francisco, P.O. Box 29910, San Francisco, CA 94129, USA.

E-mail: Luis.Solorzano@moore.org 